УДК 636.39:619:616.99:619:615

(C) 2014

Свстаф'єва В. О., доктор ветеринарних наук, професор,

Корчан Л. М., Корчан М. І., кандидати ветеринарних наук,

Мордовцева О. М., студентка V курсу ФВМ

Полтавська державна аграрна академія

\title{
ЕЙМЕРІОЗ КІЗ В УМОВАХ ОСОБИСТИХ ПІДСОБНИХ ГОСПОДАРСТВ МІСТА ПОЛТАВА
}

\section{Рецензент - доктор ветеринарних наук, професор Б. П. Киричко}

Наведені дані щзоо поширення, вікової та сезонної динаміки еймеріозу кіз в особистих підсобних господарствах міста Полтава. Видовий склад збудників еймеріозу кіз представлений шістьмома видами: Eimeria arloingi - 56\%; E. caprina - 30\%; E. alijevi $28 \%$; E. ninakohlyakimovae - $15 \%$; E. jolchijevi $12 \%$; E. christenseni - 6\%. Екстенсивність еймеріозної інвазї̈ у козенят становила 63-100\%, у кіз віком старше одного року, в середньому, $85 \%$. У $56 \%$ уражених тварин інтенсивність інвазії коливалася від кількох сотень до 10 тисяч ооцист у грамі фекалій. Найсприйнятливішим до еймеріозу був молодняк кіз віком від 16 днів до 4 місячів. Наведені дані з терапевтичної ефективності протиеймеріозних засобів за даної інвазії. Максимальну ефективність за еймеріозу кіз показали «Бровасептол» (ефективність $100 \%) i$ «Ампролінвет» $12,5 \%(I E=98,8 \%, E E=60,0 \%)$.

Ключові слова: еймеріоз, кози, протиеймеріозні препарати.

Постановка проблеми. Еймеріоз - це переважно гостре ензоотично асоціативне захворювання молодняку ссавців і птиці, збудниками якого є одноклітинні, облігатно моноксенні паразити роду Eimeria.

Захворювання характеризується загальним пригніченням, діареєю (нерідко 3 домішками крові), виснаженням і часто ускладнюється в разі одночасного ураження тварин еймеріями, нематодами чи збудниками шлунково-кишкових інфекцій.

Еймерії паразитують переважно в клітинах слизової оболонки кишок.

Тварини заражаються аліментарно, споживаючи корми і воду, що інвазовані ооцистами еймерій [1, 5-7].

Еймеріози тварин надзвичайно поширені на всіх континентах світу. Вони призводять до значних економічних збитків у тваринництві й вивчені передусім у великої рогатої худоби, овець, свиней, кролів і птиці [5-9].

Що стосується питання поширення еймеріозу кіз в Україні й, зокрема, в Полтавській області, то дане захворювання практично не вивчалося.
Аналіз останніх досліджень і публікацій, у яких започатковано розв'язання проблеми. Проблема еймеріозу дрібної рогатої худоби, зокрема, кіз, тривалий час залишалася поза полем зору науковців. Та інформація, що стосується даної інвазії, висвітлює переважно проблеми вівчарства $[1,5,7]$.

За окремими літературними даними, екстенсивність даної інвазії серед кіз у світі становить близько 40-100\% [5, 8-7].

На сьогодні для боротьби 3 даним захворюванням пропонується чимало протиеймеріозних препаратів, однак еймеріоз у кіз продовжує залишатися досить актуальною й маловивченою проблемою $[8,9]$.

Мета і завдання дослідження. Мета роботи полягала у вивченні поширення, патогенезу та лікування еймеріозу кіз.

У завдання дослідження входили такі задачі:

- вивчити поширення, вікової та сезонної динаміки еймеріозу кіз, які утримуються в умовах особистих підсобних господарств;

- з'ясувати гематологічні зміни за даної інвазії;

- визначити ефективність протиеймеріозних препаратів, до складу яких входять різні хіміотерапевтичні діючі речовини.

Матеріали і методи досліджень. Дослідження проводили протягом 2012-2013 року на базі наукових лабораторій кафедри паразитології та ветеринарно-санітарної експертизи, а також кафедри терапії Полтавської державної аграрної академії.

Експериментальні дослідження виконували на козенятах віком від двох діб до семи місяців і кіз 1-4-річного віку, які належать власникам особистих підсобних господарств міста Полтава. Всього досліджено 240 тварин.

Для проведення копроскопічних досліджень у кіз індивідуально відбирали зразки фекалій із прямої кишки за допомогою приладу для відбору проб фекалій у дрібної рогатої худоби [2].

Копроскопічні дослідження проводили за способом Трача В.Н. із використанням у якості 


\section{ВЕТЕРИНАРНА МЕДИЦИНА}

флотаційного розчину аміачної селітри з густиною 1,295. Підрахунок кількості ооцист еймерій в 1 г фекалій проводили згідно з ДСТУ 25383-82 (СТ СЗВ 2547-80). Видову належність еймерій визначали шляхом культивування у $2 \%$ розчині біхромату калію за температури $30{ }^{\circ} \mathrm{C}$ протягом семи діб. У роботі користувалися класифікатором М. В. Крилова [3, 6].

Гематологічні дослідження крові хворих кіз проводили за загальноприйнятими методами [4].

3 метою вивчення терапевтичної ефективності 3 урахуванням принципу аналогів було сформовано п’ять груп (чотири дослідних і контрольна) козенят по десять голів у кожній, яким вводили препарати перорально індивідуально щодня протягом двох чотириденних курсів лікування 3 iнтервалом у три доби:

- першій групі козенят задавали «Бровітакокцид», у дозі 4 г/10 кг маси тіла;

- другій групі тварин - «Ампролінвет» 12,5 \%, у дозі 4 г/10 кг маси тіла;

- третій групі козенят - «Байкокс» $5 \%$, у дозі 3 мл суспензії на 10 кг маси тіла;

- четвертій групі тварин - «Бровасептол» у дозі на перший день 2 г/10 кг, далі - 1,2 г/10 кг маси тіла.

П’ята група козенят була контрольною - тварини препаратів не отримували.

Протиеймеріозні препарати «Бровітакокцид» i «Ампролінвет» $12,5 \%$ містять діючу речовину ампроліум (в 1 г препарату 125 мг ДР). «Байкокс» $5 \%$ в 1 мл лікарського засобу в якості діючої речовини міститься 50 мг толтразурилу. Препарат «Бровасептол» відносять до комбінованих препаратів, у 1 г якого міститься 80 мг норсульфазолу, 70 мг сульгіну, 30 мг триметоприму, 45 мг оксітетрацикліну гідрохлориду i 25 мг тілозину тартрату.

Ефективність випробуваних протиеймеріозних препаратів досліджували за зміною показників екстенсивності (ЕI) та інтенсивності (II) еймеріозної інвазії до і на 12-ту та 24-ту добу після ведення препаратів. На основі отриманих даних визначали показники інтенс- та екстенсефективності (IE, EЕ) препаратів.

Результати досліджень. У процесі дослідження виявили, що в умовах міста Полтава екстенсивність еймеріозної інвазії у кіз, залежно від їх віку та сезону, становить від 63 до 100 \%; інтенсивність еймеріозної інвазії коливалася від кількох сотень до 10 тисяч ооцист у грамі фекалій.

Результати вивчення вікової динаміки еймеріозу кіз свідчать про те, що показники ЕI та II залежать від віку тварин. Перші ооцисти еймерій виявляли у козенят уже в 16-денному віці. Екс- тенсивність інвазії (ЕI) становила $63 \%$, у разі невисокої інтенсивності інвазії (II) - від 17 до 86 ооцист у грамі фекалій (далі - ОГФ). До 20-го дня життя ЕI зростала до 78 \%, а II у заражених козенят коливалася в межах від 127 i до 767 ОГФ. У козенят місячного віку продовжували зростати показники ЕI до 85 \%, та II - від 357 до 5798 ОГФ. ЕІ у козенят 2-3-місячного віку сягає 90-100\%, а інтенсивність - 10 тисяч ОГФ. У віці 4-6 місяців інвазованість козенят залишається на високому рівні (90-100\%), а II знижується до 2678-3260 ОГФ. У козенят 6-місячного віку EI і II знижуються, відповідно, до 75 \% і від 105 до 1350 ОГФ. Такий рівень зараженості зберігається у козенят до року.

У молодняку 1-2 років і дорослих тварин ЕІ стабілізується й становить $80-100 \%$ за незначної II (від 150 до 678 ОГФ).

Сезонна динаміка еймеріозу козенят поточного року народження постійно змінюється. У зимовий період ЕІ коливається в межах 70 \% при II $274 \pm 132$ ОГФ. Навесні цей показник зростає до 80-100 \% за одночасного збільшення кількості ооцист $(2348 \pm 787)$. Влітку ЕI знаходиться в межах 90-100\%, а II зменшується до $1640 \pm 662$ ОГФ. Восени ЕІ знижується до 75 \% за поступового зниження II $-685 \pm 462$ ОГФ.

У дорослих кіз і молодняку 1-2-х років відзначені дві хвилі інвазії впродовж року: навесні та восени. Зараженість кіз у зимовий період становить $85 \%$, навесні та восени процент інвазованих тварин збільшується до 95-100 \%, а влітку зменшується до $80 \%$; II у цих вікових групах тварин протягом усього року становить від 59 до 795 ОГФ.

Встановлено, що на території міста Полтава видовий склад збудників еймеріозу кіз представлений шістьмома видами: Eimeria arloingi (Marotel, 1905, Martin, 1909) - 56\%; Eimeria caprina (Lima, 1979) - 30 \%; Eimeria alijevi (Musaev, 1970) y $28 \%$; Eimeria ninakohlyakimovae (YakimoffRastegaieff, 1930) - $15 \%$; Eimeria jolchijevi (Musaev, 1970) - 12\%; Eimeria christenseni (Levine, Ivens \& Fritz, 1962) - 6\%. У $65 \%$ зразків фекалій реєстрували 3-5 видів еймерій одночасно.

Найбільш поширеними видами еймерій у молодняку є Е. ninakohlyakimovae, E. arloingi, E. alijevi, у дорослих кіз - E. alijevi, E. jolchijevi, E. ninakohlyakimovae. Види Е. caprina i Е. christenseni зустрічалися порівняно рідко як у дорослих, так і в молодняку кіз. За клінічного обстеження козенят було виявлено: порушення роботи шлунково-кишкового тракту, диспепсію зі значною кількістю слизу та домішків крові (100\%), підвищення температури тіла до $41,5^{\circ} \mathrm{C}$ 
ВЕТЕРИНАРНА МЕДИЦИНА

Ефективність лікарських засобів за еймеріозу козенят

\begin{tabular}{|c|c|c|c|c|c|c|c|c|}
\hline \multirow{4}{*}{ № групи } & \multirow{4}{*}{$\begin{array}{c}\text { Назва та доза } \\
\text { препарату }\end{array}$} & \multicolumn{7}{|c|}{ Показники інвазії } \\
\hline & & \multirow{2}{*}{ до лікування } & \multicolumn{6}{|c|}{ після лікування } \\
\hline & & & \multicolumn{3}{|c|}{ через 12 діб } & \multicolumn{3}{|c|}{ через 24 доби } \\
\hline & & II, ОГФ & II, ОГФ & IE, \% & $\mathrm{EE}, \%$ & II, ОГФ & IE, $\%$ & $\mathrm{EE}, \%$ \\
\hline 1 & $\begin{array}{c}\text { «Бровітакокцид», } \\
4 \text { г/10 кг }\end{array}$ & $\begin{array}{r}1091,6 \\
\pm 216,9\end{array}$ & $\begin{array}{l}382,0 \\
\pm 75,9\end{array}$ & 72,3 & 0 & $\begin{array}{l}272,2 \\
\pm 90,8\end{array}$ & 85,8 & 30,0 \\
\hline 2 & $\begin{array}{c}\text { «Ампролінвет» } \\
12,5 \%, \\
4 \text { г/10 кг }\end{array}$ & $\begin{array}{l}1416,5 \\
\pm 199,4\end{array}$ & $\begin{array}{l}33,5 \\
\pm 9,8\end{array}$ & 98,0 & 40,0 & $\begin{array}{l}29,3 \\
\pm 13,4\end{array}$ & 98,8 & 60,0 \\
\hline 3 & $\begin{array}{c}\text { «Байкокс» } 5 \%, \\
3 \text { мл/10 кг }\end{array}$ & $\begin{array}{c}979,5 \\
\pm 158,3\end{array}$ & $\begin{array}{c}801,9 \\
\pm 130,0\end{array}$ & 35,3 & 0 & $\begin{array}{r}726,9 \\
\pm 121,3\end{array}$ & 57,6 & 0 \\
\hline 4 & $\begin{array}{c}\text { «Бровасептол», } \\
1-\text { й день - } 2 \text { г/10 кг, } \\
\text { далі }-1,2 \text { г/10 кг }\end{array}$ & $\begin{array}{l}1595,7 \\
\pm 181,0\end{array}$ & $\begin{array}{l}2,7 \\
\pm 2,7\end{array}$ & 99,9 & 90,0 & 0 & 100 & 100 \\
\hline 5 & контроль & $\begin{array}{l}1010,3 \\
\pm 168,7\end{array}$ & $\begin{array}{l}1278,1 \\
\pm 237,4\end{array}$ & - & - & $\begin{array}{l}1769,8 \\
\pm 261,4\end{array}$ & - & - \\
\hline
\end{tabular}

із погіршенням загального стану - $(35 \%)$. У дорослих кіз віком 1-4 роки відмічали переважно субклінічний перебіг хвороби. За гематологічного дослідження у козенят, хворих на еймеріоз, виявляли лейкоцитоз (23 Г/л), гіпорегенеративне зрушення нейтрофільного ядра вліво, підвищення швидкості осідання еритроцитів (у середньому 6 мм/год) та олігохромемію (близько 9 г/100 мл), зменшення кількості еритроцитів (11,33 Т/л), вмісту гемоглобіну (74 г/л).

Результати копрологічних досліджень щодо визначення ефективності лікування козенят за умов спонтанного зараження їх еймеріями наведені в таблиці. Так, на 12-у добу після початку досліду інтенсефективність (IE) бровітакокциду становила 72,3 \% за $100 \%$ екстенсивності інвазії.

На 28-у добу дослідження IE і EЕ «Бровітакокциду» становила, відповідно, 98,8 \% і 60,0\%. Препарат «Ампролінвет» 12,5 \% на 12 -у добу експерименту 98,0\% інтенсенефективність і $40,0 \%$ екстенсефективність. На 28 добу IE і ЕE становила, відповідно, 98,8 \% і 60,0\%. У тварин третьої групи на 12-у добу після введення препарату «Байкокс» $5 \%$ відмічали незначне зниження інтенсивності еймеріозної інвазії $(\mathrm{IE}=35,3 \%)$ за $\mathrm{EI}=100 \%$. На 28-у добу дослідження після введення препарату «Байкокус» $5 \%$ дещо зменшилася кількість ооцист ( $\mathrm{IE}=35,3$ \%, EI=100 \%). Препарат «Бровасептол», порівняно $з$ попередніми препаратами, показав вищу інтенс- та екстенсефективність за еймеріозної інвазії, що становила на 12-ту добу, відпові- дно, 99,9 \% та 90,0 \%, а на 24-у добу його ефективність була $100 \%$. Після проведення хіміотерапії клінічний стан тварин усіх чотирьох дослідних груп, порівняно 3 тваринами контрольної групи, значно поліпшився.

Перспективи подальших досліджень полягають у вивчені морфологічних і біохімічних показників крові козенят і кіз за використання протиеймеріозного препарату «Бровасептолу».

\section{Висновки:}

1.У результаті проведених досліджень встановлено, що екстенсивність еймеріозної інвазії у козенят особистих підсобних господарств міста Полтава становила 63-100 \%, у кіз віком старше одного року, в середньому, $\mathrm{EI}=85 \%$. У $56 \%$ уражених тварин інтенсивність еймеріозної інвазії коливалася від кількох сотень до 10 тисяч ОГФ. Найсприйнятливішим до еймеріозу був молодняк кіз віком від 16 діб до 4 місяців.

2. У козенят поточного року народження найвища ЕI відмічається у весняно-літній період

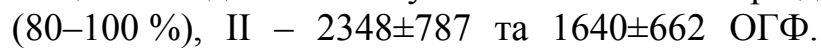
У дорослих тварин і молодняку віком 1-2 роки відзначають дві хвилі інвазії: навесні та восени.

3. Встановлено, що паразитофауна еймерій кіз на території м. Полтава представлена шістьмома видами: Eimeria arloingi (Marotel, 1905, Martin, 1909) - 56 \%; Eimeria caprina (Lima, 1979) - $30 \%$; Eimeria alijevi (Musaev, 1970) y $28 \%$; Eimeria ninakohlyakimovae (Yakimoff-Rastegaieff, 1930) $15 \%$; Eimeria jolchijevi (Musaev, 1970) - 12\%; Eimeria christenseni (Levine, Ivens \& Fritz, 1962) - 6\%. 


\section{ВЕТЕРИНАРНА МЕДИЦИНА}

4. За гематологічного дослідження крові у козенят, хворих на еймеріоз, виявляли лейкоцитоз (23 Г/л), гіпорегенеративне зрушення нейтрофільного ядра вліво, підвищення швидкості осідання еритроцитів (у середньому 6 мм/год) та олігохромемію (близько 9 г/100 мл), зменшення

\section{БІБЛІОГРАФІЯ}

1. Вершинин И. И. Кокцидиозы животных и их дифференциальная диагностика. - Екатеринбург, 1996. - 264 c.

2. Корчан Л. М. Прилад для відбору проб фекалій у дрібної рогатої худоби / Л. М. Корчан // Ветеринарна медицина України. - 2009. - № 8. C. $28-29$.

3. Крылов М. В. Определитель паразитических простейших. - С.-Пб. : Наука, 1996. - 602 с.

4. Кудрявиев А. А. Клиническая гематология животных / А. А. Кудрявцев, Л. А. Кудрявцева. М. : Колос, 1974. - 339 с.

5. Приходько Ю. А. Эймериоз овец и усовершенствование мер борьбы с ним: автореф. дис. ... канд. вет. наук: специальность 16.00.11 - «Паразитология» / Ю. А. Приходько. - Х., 1986. - 27 с.

6. Рекомендації щодо гельмінтологічних кількості еритроцитів (11,33 Т/л), вмісту гемоглобіну (74 г/л).

5. Найбільш ефективними лікарськими засобами за еймеріозу кіз виявилися «Бровасептол» (ефективність - $100 \%$ ) і «Ампролінвет» 12,5\% $(\mathrm{IE}=98,8 \%, \mathrm{EE}=60,0 \%)$.

досліджень тварин / С. І. Пономар, Н. М. Сорока, О. П. Литвиненко [та ін.] - Біла Церква, 2008. $78 \mathrm{c}$.

7. Якубовский М. В. Паразитарные болезни животных / М. В. Якубовский, Н. Ф. Карасев. Мн. : Ураджай, 1991. - 256 с.

8. Coccidiosis in goats and prevention [Електронний pecypc] / Alabama and auburn universities. Режим доступу: http://www.aces.edu/pubs/docs /U/UNP0109/UNP-0109.pdf.

9. Ruiz A. Influence of climatic and management factors on Eimeria infections in goats from semiarid zones / A. Ruiz, J. González // Journal of Veterinary Medicine B., Infectious Diseases and Veterinary Public Health. - 2006. - № 53(8). P. 399-402. 